\title{
Development of Economic Herbal Based Drug Substitute from Citrus paradisi (Grape fruit) for Existing Anti-anxiety Drug Modules
}

\author{
Vikas Gupta ${ }^{1 *}$, Parveen Bansal ${ }^{1}$, Kamlesh Kohli ${ }^{2}$ and Pankaj Ghaiye ${ }^{3}$
}

${ }^{1}$ University Centre of Excellence in Research, BFUHS, Faridkot, India

${ }^{2}$ Department of Pharmacology, GGSMC, BFUHS, Faridkot, India

${ }^{3}$ Akal College of Pharmacy and Technical Education, Sangrur, India

\begin{abstract}
Persistent and unrelenting stress often leads to anxiety and unhealthy behavior. Benzodiazepines are used as a first line of treatment however difficulties with pharmacotherapy of anxiety disorders such as dependence and low response rate encourage researchers to find new approaches. A number of studies have been done on antianxiety activity of medicinal plants but major constraint is non suitability of the tested plant material for human use and non availability of plant materials in bulk at economical rates. This study entails to development of safe anti-anxiety economic drug of easy availability. In normal course aromatic oils from plant are being used however authors selected four varieties of plant Citrus paradisi available worldwide and tested the anti-anxiety activity of leaf extracts as leaf extracts can be made available at commercial scale. All the selected varieties have demonstrated a potential diazepam like effect in methanolic extracts at a dose of $100 \mathrm{mg} / \mathrm{kg}$ body weight using elevated plus maze model. The results strongly justify the use of Citrus paradisi leaf extracts for treatment of anxiety. Further studies are in progress to find out active component involved in the anti-anxiety effect.
\end{abstract}

Keywords: Anxiety; Citrus paradise; Diazepam; Elevated plus maze

\section{Introduction}

Stress and anxiety are common psychiatric manifestations of the modern world and lifestyles. In small quantities, stress and anxiety are good; they can motivate and help one be more productive. However, too much stress, or a strong response to stress, is harmful. It can set up for general poor health as well as specific physical or psychological illnesses like infection, heart disease, or depression. Persistent and unrelenting stress often leads to anxiety and unhealthy behaviors. Anxiety is a Central Nervous System disorder with emotional state, unpleasant in nature, associated with uneasiness, discomfort and concern or fear about some defined or undefined future threat $[1,2]$.

\section{Therapies available and limitations}

Benzodiazepines are used as a first line of treatment. Today, at least 20 million people worldwide are prescribed these "minor tranquilizers." Meanwhile, Western European and North American countries are facing epidemic levels of citizens hooked on these drugs. While benzodiazepines are a disaster in terms of the public health, pharmaceutical companies rake in a whopping \$21 (€ 14 billion) billion a year selling them. So, difficulties with pharmacotherapy of anxiety disorders such as dependence and low response rate encourage researchers to find new approaches [3].

\section{Alternative therapies}

From the past, the role of medicinal plants has been a subject of intense interest. A number of studies have been done on anti-anxiety activity of medicinal plants but major constraint towards development of a marketable formulation is non suitability of the tested plant material for human use and non availability of plant materials in bulk at economical rates. This study entails to development of safe anti-anxiety economic drug of easy availability. In normal course aromatic oils from plant are being used for antianxiety activity but the cost of aromatic oils and its availability and cumbersome administration procedure creates a limitation for a market product. At the same time aromatic oils can be used topically or for inhalation purposes whereas leaf extracts can be a better medium for formulation development which can be easily administered.
Citrus fragrances have been particularly attributed with mood enhancing properties by aroma therapists. The volatile oils obtained from genus Citrus (Citrus paradisi) have been recommended and used for the treatment of anxiety. A review of literature also reflects that Citrus paradisi is widely employed in herbal medicine and aromatherapy and significant work has already been reviewed and carried out by authors on the anxiolytic effects of the plant extracts [4-10].

In this study authors intend to select four varieties of plant Citrus paradisi available worldwide and test the anti-anxiety activity of leaf extracts as leaf extracts can be made available at commercial scale. So, the present study was designed to develop an economic herbal based drug substitute for existing anti-anxiety drug modules using different varieties of different extracts of Citrus paradisi using the EPM, an exteroceptive behavior animal model.

\section{Materials and Methods}

\section{Plant material}

The leaves of Citrus paradisi of four different varieties i.e duncan, foster, marshseedless and star ruby were procured from a identified and cultivated source: Punjab Agricultural University, Regional Centre, Abohar (Punjab, India) in the month of March-April, 2013.

\section{Preparation of extracts}

Leaves of different varieties were dried in shade and powdered. The powdered leaves $(100 \mathrm{~g})$ were subjected to successive Soxhlet extraction by solvents in increasing order of polarity viz. petroleum ether (60-

*Corresponding author: Vikas Gupta, University Centre of Excellence in Research, BFUHS, Faridkot, India, Tel: 09914933022; E-mail: vikas_4308@ rediffmail.com

Received July 01, 2014; Accepted July 18, 2013; Published July 20, 2013

Citation: Gupta V, Bansal P, Kohli K, Ghaiye P (2014) Development of Economic Herbal Based Drug Substitute from Citrus paradisi (Grape fruit) for Existing Anti-anxiety Drug Modules. Nat Prod Chem Res S1:001. doi:10.4172/23296836.S1-001

Copyright: $\odot 2014$ Gupta V, et al. This is an open-access article distributed under the terms of the Creative Commons Attribution License, which permits unrestricted use, distribution, and reproduction in any medium, provided the original author and source are credited. 
$80^{\circ} \mathrm{C}$ ), chloroform, methanol and water. Before each extraction the powdered material was dried in hot air-oven below $50^{\circ} \mathrm{C}$. Each extract was concentrated by distilling off the solvent and then evaporating to dryness on the water-bath.

\section{Test animals}

The experimental animals [Swiss albino mice (20-30 g) of either sex] were procured from the approved animal House, Akal College of Pharmacy and Technical Education, Mastuana Sahib, Sangrur. (IAEC No. ATRC/05/13). The animals were given standard laboratory feed and water ad libitum. The experiments were performed between 6.00 am to $11.00 \mathrm{am}$. The experiments were conducted in a semi-sound proof laboratory. All the experimental procedures and protocols used in the study were duly reviewed and approved by the Institutional Animal Ethics Committee.

\section{Anti-anxiety activity}

Animals were divided into six (I-VI) groups for each variety of source plant.

For each variety

1. Group I was a negative control and administered only vehicle (consisting of simple syrup IP and carboxy methyl cellulose (5\%).

2. Group II was a positive control and was given standard drug, diazepam $(2 \mathrm{mg} / \mathrm{kg}$, orally), suspended in the vehicle.

3. Group III-VI were treated as test groups and were given petroleum ether $\left(60-80^{\circ} \mathrm{C}\right)$, chloroform, methanol and water extracts of different varieties from the leaves of Citrus paradisi at different doses viz. 50,100, 200 and $400 \mathrm{mg} / \mathrm{kg}$ body weight respectively. Mice were treated orally with all the test solutions, standard drug and control for 5 days once daily at a stipulated time and last dose was given on the $5^{\text {th }}$ day, 45 minutes prior to study.

\section{Elevated plus maze model (EPM)}

The elevated plus-maze model is well established animal model for testing anxiolytic drugs. The elevated plus-maze apparatus consist of two open arms $(16 \times 5 \mathrm{~cm}$ for mice and $50 \times 10 \mathrm{~cm}$ for rats), two closed arms $(16 \times 5 \times 12 \mathrm{~cm}$ for mice and $50 \times 10 \times 40 \mathrm{~cm}$ for rats), and an open roof with the entire maze elevated $(25 \mathrm{~cm}$ for mice and $50 \mathrm{~cm}$ for rats) from the floor. The animals were placed individually in the centre of the maze, head facing towards open arms [11,12].

\section{Statistical analysis}

The anxiolytic activities of the extracts, diazepam and control were analyzed by one-way analysis of variance (ANOVA). The test groups were compared with standard/control by Dunnett Multiple Range Test. Difference were considered significant at $\mathrm{p}<0.05$.

\section{Results and Discussion}

\section{Acute toxicity study}

Acute oral toxicity studies revealed the non-toxic nature of different extracts of different varieties of Citrus paradisi. There was no morbidity observed or any profound toxic reactions found at a dose of up to 2000 $\mathrm{mg} / \mathrm{kg}$ body weight, which indirectly reflects the safety profile of the plant extract.

\section{Anti-anxiety activity}

The results obtained from the EPM model, indicate that methanolic extract of all the varieties showed significant $(\mathrm{p}<0.05)$ anti anxiety activity as compared to control and was almost at par with standard drug diazepam. At $50 \mathrm{mg} / \mathrm{kg}$ of body weight there was an increase in the time spent in open arms when the mice were administered leaf extracts from all the varieties. The average time spent in open arms further increased from $7.987 \pm 0.613(\mathrm{sec})$ in control to $21.750 \pm 0.243$ $(\mathrm{sec})$ in methanolic extract at a dose of $100 \mathrm{mg} / \mathrm{kg}$ of Citrus paradisi var. foster, from $8.642 \pm 0.351$ (sec) in control to $23.143 \pm 0.520$ (sec) in Citrus paradisi var. duncan., from $10.023 \pm 0.850$ (sec) in control to $25.050 \pm 0.369$ (sec) Citrus paradisi var. marshseedless and from 5.837 $\pm 0.585(\mathrm{sec})$ in control to $20.948 \pm 0.651$ (sec) in Citrus paradisi var. staruby. At a higher dose of $200 \mathrm{mg} / \mathrm{kg}$ the leaf extracts demonstrated

\begin{tabular}{|c|c|c|c|c|c|c|c|}
\hline \multirow{3}{*}{ Group } & \multirow{3}{*}{ Treatment } & \multicolumn{6}{|c|}{ Average time spent in open arms (in sec) } \\
\hline & & \multicolumn{4}{|c|}{ Extracts } & \multicolumn{2}{|c|}{ Control } \\
\hline & & $\begin{array}{l}\text { Petroleum ether } \\
\text { (Mean } \pm \text { SEM) }\end{array}$ & $\begin{array}{c}\text { Chloroform } \\
\text { (Mean } \pm \text { SEM) }\end{array}$ & $\begin{array}{c}\text { Methanol } \\
\text { (Mean } \pm \text { SEM) }\end{array}$ & $\begin{array}{c}\text { Aqueous } \\
\text { (Mean } \pm \text { SEM) }\end{array}$ & $\begin{array}{c}\text { Negative } \\
(\text { Mean } \pm \text { SEM) }\end{array}$ & $\begin{array}{c}\text { Positive } \\
\text { (Mean } \pm \text { SEM) }\end{array}$ \\
\hline I & Vehicle & - & - & - & - & $7.987 \pm 0.613$ & - \\
\hline II & Diazepam & - & - & - & - & - & $24.567 \pm 0.683^{*}$ \\
\hline III & $50 \mathrm{mg} / \mathrm{kg}$ & $13.258 \pm 0.269^{*}$ & $16.742 \pm 0.331^{*}$ & $18.382 \pm 0.321^{*}$ & $13.422 \pm 0.820^{\star}$ & - & - \\
\hline IV & $100 \mathrm{mg} / \mathrm{kg}$ & $13.516 \pm 0.490^{*}$ & $17.940 \pm 0.330^{\star}$ & $21.750 \pm 0.243^{\star}$ & $12.122 \pm 0.759^{\star}$ & - & - \\
\hline V & $200 \mathrm{mg} / \mathrm{kg}$ & $11.425 \pm 0.298$ & $14.345 \pm 0.691^{*}$ & $18.218 \pm 0.226^{\star}$ & $14.685 \pm 0.354^{*}$ & - & - \\
\hline VI & $400 \mathrm{mg} / \mathrm{kg}$ & $10.887 \pm 0.217$ & $11.910 \pm 0.437$ & $13.988 \pm 1.056^{*}$ & $11.197 \pm 0.997$ & - & - \\
\hline
\end{tabular}

Values are Mean \pm SEM $(n=6)$; One way ANOVA and Dunnett multiple range test. ${ }^{*} p<0.05$ compared to control

Table 1: Anti-anxiety activity of various extracts of leaves of Citrus paradisi var. foster using EPM.

\begin{tabular}{|c|c|c|c|c|c|c|c|}
\hline \multirow{3}{*}{ Group } & \multirow{3}{*}{ Treatment } & \multicolumn{6}{|c|}{ Average time spent in open arms (in sec) } \\
\hline & & \multicolumn{4}{|c|}{ Extracts } & \multicolumn{2}{|l|}{ Control } \\
\hline & & $\begin{array}{l}\text { Petroleum ether } \\
\text { (Mean } \pm \text { SEM) }\end{array}$ & $\begin{array}{l}\text { Chloroform } \\
\text { (Mean } \pm \text { SEM) }\end{array}$ & $\begin{array}{c}\text { Methanol } \\
\text { (Mean } \pm \text { SEM) }\end{array}$ & $\begin{array}{c}\text { Aqueous } \\
\text { (Mean } \pm \text { SEM) }\end{array}$ & $\begin{array}{c}\text { Negative } \\
(\text { Mean } \pm \text { SEM) }\end{array}$ & $\begin{array}{c}\text { Positive } \\
\text { (Mean } \pm \text { SEM) }\end{array}$ \\
\hline 1 & Vehicle & - & - & - & - & $8.642 \pm 0.351$ & - \\
\hline II & Diazepam & - & - & - & - & - & $25.502 \pm 0.684^{*}$ \\
\hline III & $50 \mathrm{mg} / \mathrm{kg}$ & $11.987 \pm 0.568$ & $16.583 \pm 0.463^{*}$ & $18.560 \pm 0.549^{*}$ & $14.060 \pm 1.065^{*}$ & - & - \\
\hline IV & $100 \mathrm{mg} / \mathrm{kg}$ & $15.113 \pm 0.714^{\star}$ & $15.137 \pm 0.649^{\star}$ & $23.143 \pm 0.520^{*}$ & $15.437 \pm 0.812^{*}$ & - & - \\
\hline V & $200 \mathrm{mg} / \mathrm{kg}$ & $13.818 \pm 0.412^{*}$ & $15.078 \pm 0.681^{\star}$ & $18.900 \pm 0.655^{*}$ & $13.837 \pm 0.546^{*}$ & - & - \\
\hline $\mathrm{VI}$ & $400 \mathrm{mg} / \mathrm{kg}$ & $10.895 \pm 0.434$ & $10.747 \pm 0.622$ & $13.47 \pm 0.951^{*}$ & $10.753 \pm 0.828$ & - & - \\
\hline
\end{tabular}

Values are Mean \pm SEM $(n=6)$; One way ANOVA and Dunnett multiple range test. ${ }^{*} p<0.05$ compared to control

Table 2: Anti-anxiety activity of various extracts of leaves of Citrus paradisi var. duncan using EPM. 
Citation: Gupta V, Bansal P, Kohli K, Ghaiye P (2014) Development of Economic Herbal Based Drug Substitute from Citrus paradisi (Grape fruit) for Existing Anti-anxiety Drug Modules. Nat Prod Chem Res S1:001. doi:10.4172/2329-6836.S1-001

Page 3 of 2

\begin{tabular}{|c|c|c|c|c|c|c|c|}
\hline \multirow{3}{*}{ Group } & \multirow{3}{*}{ Treatment } & \multicolumn{6}{|c|}{ Average time spent in open arms (in sec) } \\
\hline & & \multicolumn{3}{|c|}{ Extracts } & \multicolumn{2}{|c|}{ Control } & \multirow[b]{2}{*}{$\begin{array}{c}\text { Positive } \\
\text { (Mean } \pm \text { SEM }\end{array}$} \\
\hline & & $\begin{array}{l}\text { Petroleum ether } \\
\text { (Mean } \pm \text { SEM) }\end{array}$ & $\begin{array}{l}\text { Chloroform } \\
\text { (Mean } \pm \text { SEM) }\end{array}$ & $\begin{array}{c}\text { Methanol } \\
\text { (Mean } \pm \text { SEM) }\end{array}$ & $\begin{array}{c}\text { Aqueous } \\
\text { (Mean } \pm \text { SEM) }\end{array}$ & $\begin{array}{c}\text { Negative } \\
\text { (Mean } \pm \text { SEM) }\end{array}$ & \\
\hline I & Vehicle & - & - & - & - & $10.023 \pm 0.850$ & - \\
\hline II & Diazepam & - & - & - & - & - & $26.133 \pm 0.692$ \\
\hline III & $50 \mathrm{mg} / \mathrm{kg}$ & $13.165 \pm 0.568^{\star}$ & $16.887 \pm 0.561^{*}$ & $19.150 \pm 0.571^{*}$ & $15.322 \pm 0.700^{*}$ & - & - \\
\hline IV & $100 \mathrm{mg} / \mathrm{kg}$ & $16.690 \pm 0.461^{*}$ & $18.328 \pm 0.392^{*}$ & $25.050 \pm 0.369^{*}$ & $18.695 \pm 0.695^{*}$ & - & - \\
\hline V & $200 \mathrm{mg} / \mathrm{kg}$ & $13.728 \pm 0.541^{*}$ & $15.772 \pm 0.227^{*}$ & $18.155 \pm 0.326^{*}$ & $14.920 \pm 0.396^{*}$ & - & - \\
\hline VI & $400 \mathrm{mg} / \mathrm{kg}$ & $11.003 \pm 0.414$ & $11.378 \pm 0.379$ & $13.298 \pm 0.522^{*}$ & $12.735 \pm 0.677$ & - & - \\
\hline
\end{tabular}

Values are Mean \pm SEM $(n=6)$; One way ANOVA and Dunnett multiple range test. " $p<0.05$ compared to control

Table 3: Anti-anxiety activity of various extracts of leaves of Citrus paradisi var. marshseedless using EPM.

\begin{tabular}{|c|c|c|c|c|c|c|c|}
\hline \multirow{3}{*}{ Group } & \multirow{3}{*}{ Treatment } & \multicolumn{6}{|c|}{ Average time spent in open arms (in sec) } \\
\hline & & \multicolumn{4}{|c|}{ Extracts } & \multicolumn{2}{|c|}{ Control } \\
\hline & & $\begin{array}{l}\text { Petroleum ether } \\
\text { (Mean } \pm \text { SEM) }\end{array}$ & $\begin{array}{c}\text { Chloroform } \\
\text { (Mean } \pm \text { SEM) }\end{array}$ & $\begin{array}{c}\text { Methanol } \\
\text { (Mean } \pm \text { SEM) }\end{array}$ & $\begin{array}{c}\text { Aqueous } \\
\text { (Mean } \pm \text { SEM) }\end{array}$ & $\begin{array}{c}\text { Negative } \\
\text { (Mean } \pm \text { SEM) }\end{array}$ & $\begin{array}{c}\text { Positive } \\
\text { (Mean } \pm \text { SEM) }\end{array}$ \\
\hline 1 & Vehicle & - & - & - & - & $5.837 \pm 0.585$ & - \\
\hline II & Diazepam & - & - & - & - & - & $22.158 \pm 0.963^{*}$ \\
\hline III & $50 \mathrm{mg} / \mathrm{kg}$ & $11.218 \pm 0.648^{*}$ & $16.430 \pm 0.891^{*}$ & $18.527 \pm 0.729^{*}$ & $15.207 \pm 0.481^{*}$ & - & - \\
\hline IV & $100 \mathrm{mg} / \mathrm{kg}$ & $15.840 \pm 0.743^{*}$ & $18.292 \pm 0.695^{*}$ & $20.948 \pm 0.651^{*}$ & $14.598 \pm 0.774^{*}$ & - & - \\
\hline V & $200 \mathrm{mg} / \mathrm{kg}$ & $13.030 \pm 0.839^{*}$ & $12.848 \pm 0.885^{*}$ & $15.857 \pm 0.525^{*}$ & $15.633 \pm 0.400^{*}$ & - & - \\
\hline $\mathrm{VI}$ & $400 \mathrm{mg} / \mathrm{kg}$ & $7.953 \pm 0.400$ & $10.995 \pm 0.717^{*}$ & $11.492 \pm 0.628^{*}$ & $8.758 \pm 0.941$ & - & - \\
\hline
\end{tabular}

Values are Mean \pm SEM $(n=6)$; One way ANOVA and Dunnett multiple range test. " $p<0.05$ compared to control

Table 4: Anti-anxiety activity of various extracts of leaves of Citrus paradisi var. starruby using EPM.

a sedative effect in all the varieties which further accentuated at a dose of $400 \mathrm{mg} / \mathrm{kg}$ of body weight. Results obtained have been presented in Tables 1-4.

The fear due to height induces anxiety in the animals when placed on the EPM. The ultimate manifestation of anxiety and fear in the animals is exhibited by decrease in the motor activity and preference to remain at safer places. Anxiolytic agents are expected to increase the motor activity, which is measured by the time spent by the animal in the open arms [13]. The methanol extract of four varieties of Citrus paradisi $(100 \mathrm{mg} / \mathrm{kg})$, markedly increased the percentage of average time spent by the animals in the open arms. The anxiolytic effect of the plant extract was more prominent at $100 \mathrm{mg} / \mathrm{kg}$ and doses higher or lower than this did not show a consistent anxiolytic effects. The lack of significant anxiolytic effects at doses higher than $100 \mathrm{mg} / \mathrm{kg}$ could be due to strong sedative properties of the plant extracts. Lower doses (less than $100 \mathrm{mg} / \mathrm{kg}$ ) of the plant extract did not show any significant anxiolytic effects. The anxiolytic effects of methanolic extract of four varieties of Citrus paradisi may be related to their flavonoid content. The extracts from the plant shows the presence of flavonoids and the flavonoids exert anti-anxiety activity through GABA receptors. In the CNS several flavones bind to the benzodiazepine site on the GABA A receptor resulting in sedation, anxiolytic or anti-convulsive effects. Flavonoids of several classes are inhibitors of monoamine oxidase A or $\mathrm{B}$, thereby working as anti-depressants or to improve the conditions of Parkinson's patients. Flavonoids with anxiolytic activity have been described in many plant species used in folk medicine such as Passiflora coerulea [14]. This effect has been attributed to the affinity of flavonoids for the central benzodiazepine receptors [15-17]. In another study a sedative effect on the central nervous system has been shown for quercetrin and isoquercetin glycosides in mice [18-20]. However, further studies are being carried out to identify the phytoconstituent responsible for the observed anxiolytic effect of methanol extract at dose $100 \mathrm{mg} / \mathrm{kg}$. Natural herbs/herbal mixtures that act synergistically promise to provide an effective remedy for anxiety.

\section{Conclusion}

There is a paradigm shift towards use of herbal remedies or herbal based formulations. The role of medicinal plants in disease prevention and treatment has always been remarkable. This study was conducted with an aim towards develop of safe anti-anxiety economic drug of easy availability. In normal course aromatic oils from plant are being used however authors selected four varieties of plant Citrus paradisi available worldwide and tested the anti-anxiety activity of leaf extracts as leaf extracts can be made available at commercial scale. All the selected varieties have demonstrated a potential diazepam like effect that strongly justify the use of Citrus paradisi leaf extracts for treatment of anxiety in human trials. Further studies are in progress to find out active component involved in the anti-anxiety effect. Synthetic drugs and medications possess enormous side effects whereas toxicity studies of our proposed extract have proven to be safe, so these herbs with a wide therapeutic applicability promise to alleviate anxiety with very few adverse effects.

\section{References}

1. Evans DL, Charney DS, Lewis L, Golden RN, Gorman JM, et al. (2005) Mood disorders in the medically ill: scientific review and recommendations. Biol Psychiatry 58: 175-189.

2. Gureje O, Von Korff M, Simon GE, Gater R (1998) Persistent pain and wellbeing: a World Health Organization Study in Primary Care. JAMA 280: 147-151.

3. Emamghoreishi M, Khasaki M, Aazam MF (2005) Coriandrum sativum evaluation of its anxiolytic effect in the elevated plus-maze. J Ethnopharmaco 96: $365-370$.

4. Komiya M, Takeuchi T, Harada E (2006) Lemon oil vapor causes an anti-stress effect via modulating the 5-HT and DA activities in mice. Behav Brain Res 172: 240-249.

5. Gupta V, Bansal P, Kumar P, Shri R (2009) Anxiolytic and antidepressant activities of different extracts from Citrus paradisi var. foster. Journal Pharmacy Research 2: 1864-1866.

6. Gupta V, Bansal P, Kumar P, Shri R (2010) Anxiolytic and antidepressant activities of different extracts from Citrus paradisi var. duncan. Asian Journal of 
Citation: Gupta V, Bansal P, Kohli K, Ghaiye P (2014) Development of Economic Herbal Based Drug Substitute from Citrus paradisi (Grape fruit) for Existing Anti-anxiety Drug Modules. Nat Prod Chem Res S1:001. doi:10.4172/2329-6836.S1-001

Pharmaceutical and Clinical Research 3: 98-100.

7. Gupta V, Bansal P, Kumar P, Kaur G (2010) Pharmacopoeial standards and pharmacognostical studies of leaves of Citrus paradisi var. foster. Research Journal of Pharmacognosy and Phytochemistry 2: 140-143.

8. Gupta V, Bansal P, Niazi J, Kaur G (2011) Anti-anxiety Activity of Citrus paradisi var. star ruby Extracts. International Journal of Pharm Tech Research 2: 1655-1657.

9. Gupta V, Ghaiye P, Bansal P, Shri R (2011) Pharmacopoeial standards and pharmacognostical studies of leaves of Citrus paradisi var. duncan. Journal of Pharmacy Research 4: 1084-1086.

10. Lather A, Gupta V, Chaudhary AK, Singh R, Bansal P, et al. (2012) In vitro evaluation of antimicrobial activity of Kutajghan vati - an Ayurvedic formulation. Pak J Pharm Sci 25: 693-696.

11. Gupta V, Kohli K, Ghaiye P, Bansal P, Lather A (2011) Potentials of Citrus Paradisi-An Overview. International Journal of Phytotherapy Research 1: 8-17.

12. Pellow S, Chopin P, File SE, Briley M (1985) Validation of open:closed arm entries in an elevated plus-maze as a measure of anxiety in the rat. J Neurosci Methods 14: 149-167.

13. Kulkarni SK, Reddy DS (1996) Animals Behavioral Models for Testing AntiAnxiety Agents. Methods Find Exp Clin Pharmacol 18: 219-230.
14. Kumar S, Sharma A (2005) Anti-anxiety activity studies of various extracts of Turnera aphrodisiaca Ward. J Herb Pharmacother 5: 13-21.

15. Wolfman C, Viola H, Paladini A, Dajas F, Medina JH (1994) Possible anxiolytic effects of chrysin, a central benzodiazepine receptor ligand isolated from Passiflora coerulea. Pharmacol Biochem Behav 47: 1-4.

16. Medina JH, Viola H, Wolfman C, Marder M, Wasowski C, et al. (1998) Neuroactive flavonoids: new ligands for the Benzodiazepine receptors. Phytomedicine 5: 235-243.

17. Griebel G, Perrault G, Tan S, Schoemaker H, Sanger DJ (1999) Pharmacological studies on synthetic flavonoids: comparison with diazepam. Neuropharmacology 38: 965-977.

18. Paladini AC, Marder M, Viola H, Wolfman C, Wasowski C, et al. (1999) Flavonoids and the central nervous system: from forgotten factors to potent anxiolytic compounds. J Pharm Pharmacol 51: 519-526.

19. Picq M, Cheav SL, Prigent AF (1991) Effect of two flavonoid compounds on central nervous system. Analgesic activity. Life Sci 49: 1979-1988.

20. Kang TH, Jeong SJ, Kim NY, Higuchi R, Kim YC (2000) Sedative activity of two flavonol glycosides isolated from the flowers of Albizzia julibrissin Durazz. J Ethnopharmacol 71: 321-323. 